\title{
Harmful exhaust components and particles mass and number emission during the actual drive of a passenger car in accordance with the RDE procedure
}

The article presents toxic exhaust components emission measurement results as well as solid particles mass and number. The test involved a direct gasoline injection engine, in which special attention should be paid to the particulates number emission. Small diameters of nanoparticles make them particularly dangerous to human health. Nowadays, vehicle engines are constantly improved and modernized as a result of the need to meet existing exhaust gas emission standards. One of the few ways to determine the actual content of toxic and harmful compounds in the exhaust gases is the RDE (Real Driving Emissions) procedure, the requirements of which apply from 2016 for new vehicles, and from 2019 will apply to all registered passenger cars. The RDE procedure does not replace the WLTP (World Light-Duty Vehicle Test Procedure), but complements it. The tests on the dynamometer are separated from external conditions such as traffic volume or congestion and are not a sufficient indicator of emissions in real traffic conditions.

Key words: RDE procedure, particulate mass, particulate number, exhaust emission, direct injection

\section{Introduction}

Nowadays, vehicle engines are constantly improved and modernized as a result of the need to meet existing exhaust gas emission standards. One of the few ways to determine the actual content of toxic and harmful compounds in the exhaust gases is the RDE (Real Driving Emissions) procedure, the requirements of which apply from 2016 for new vehicles, and from 2019 refer to all registered passenger cars. Increasing the popularity of engines powered by direct gasoline injection system on the global market resulted in amplified emission of particles with small diameters to the atmosphere [1]. This is directly related to the risk to human health, as it is impossible or very difficult for the organism to remove particles with a diameter of less than $100 \mathrm{~nm}$ [5].The issue of particulate filters is standard for compression-ignition engines, but for gasoline engines it is still an area to be analyzed. The tests on the engine test bench are separated from external conditions such as traffic or congestion and are not a sufficient indicator of emissions in real traffic conditions. The RDE procedure does not replace the WLTP test (World Light-Duty Vehicle Test Procedure), but is a supplement to it. The results of hydrocarbons and carbon oxides emission during the discussed studies were published in a separate article [2]. This publication, in addition to data on particle mass and number emission, presents the results of gaseous exhaust components in the form of nitrogen oxides and carbon dioxide emission measurements.

\section{Research object}

The examined object was a vehicle from the LDV group, equipped with a spark-ignition engine with direct fuel injection of a displacement of $1197 \mathrm{~cm}^{3}$ produced in 2015 (Fig. 1). The basic technical data of the engine is shown in table 1 . The tested vehicle had highline equipment, which could have an impact on fuel consumption, due to the increased weight compared to the basic equipment, mainly caused by additional comfort systems, which affects the vehicle's air resistance.
Table 1. Basic engine technical data

\begin{tabular}{|l|c|}
\hline Engine type & spark-ignition \\
\hline Displacement $\left[\mathrm{cm}^{3}\right]$ & 1197 \\
\hline Number of cylinders/valves & $4 / 16$ (straight) \\
\hline Injection type & direct \\
\hline Power $[\mathrm{kW}]$ & 77 \\
\hline Maximum torque $[\mathrm{Nm}]$ & 160 \\
\hline Gearbox & automatic/DSG \\
\hline
\end{tabular}

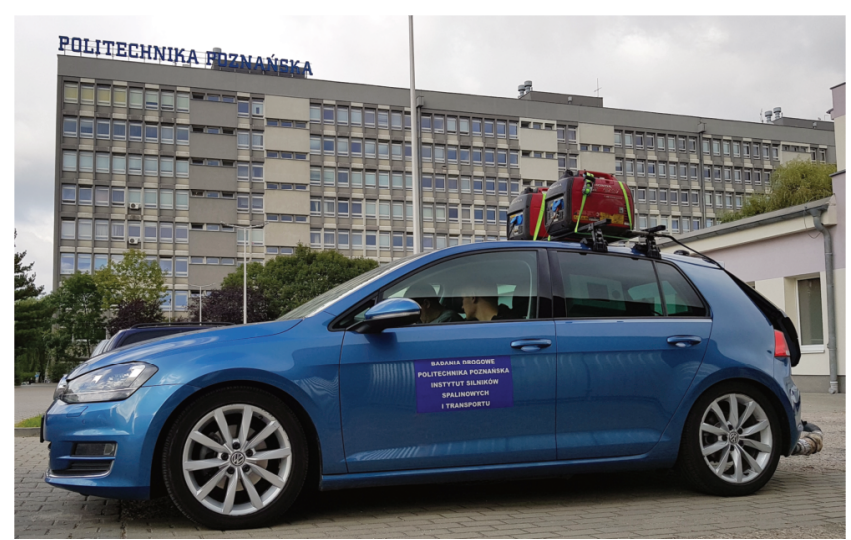

Fig. 1. Research object

\section{Research methodology}

\subsection{Measuring equipment}

The equipment from the PEMS group was used for the tests, which contained a number of analyzers for the harmful compounds measurement such as: carbon dioxide $\left(\mathrm{CO}_{2}\right)$, carbon monoxide $(\mathrm{CO})$, hydrocarbons $(\mathrm{HC})$, solid particulates in mass (PM) and number (PN) range (Fig. 2) [3]. The apparatus before the test was calibrated with standard gases according to the procedure provided by the manufacturer. Moreover, just before the vehicle left for the route, the equipment was zeroed in the ambient air, so as to make the obtained results independent of the background contamination. 


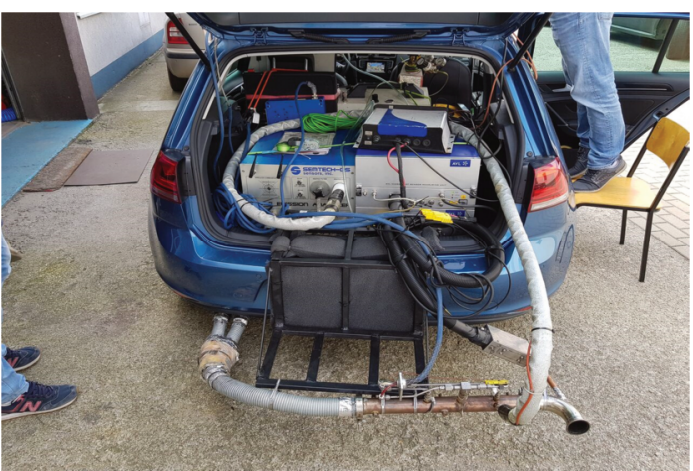

b)
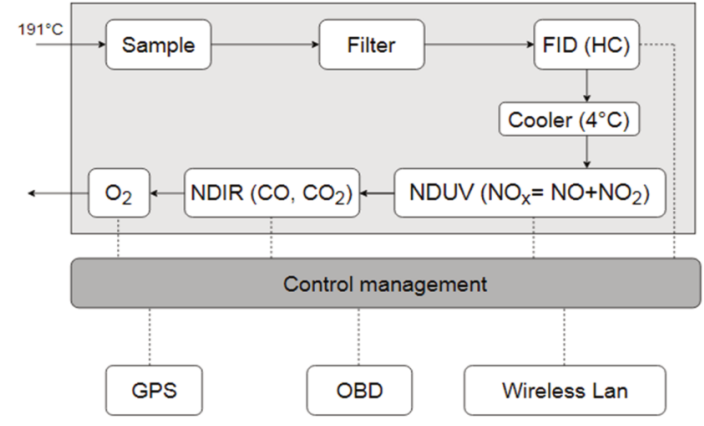

Fig. 2. SEMTECH DS analyzer: a) device view, b) operation diagram

Particulate measurements are particularly important for modern vehicles with spark-ignition engines and direct fuel injection. Research on their impact on human health led to the introduction of limits, at the beginning of the mass, and then the number of particulates for compression-ignition engines. From September 2017, the limit of particle numbers also applies to vehicles with SI DI engines. For this reason, it is required to use two analyzers - one used to determine the mass and the other to the number (Fig. 3). a)

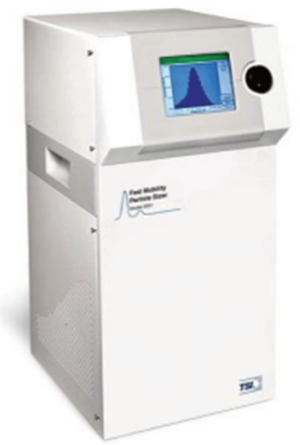

b)

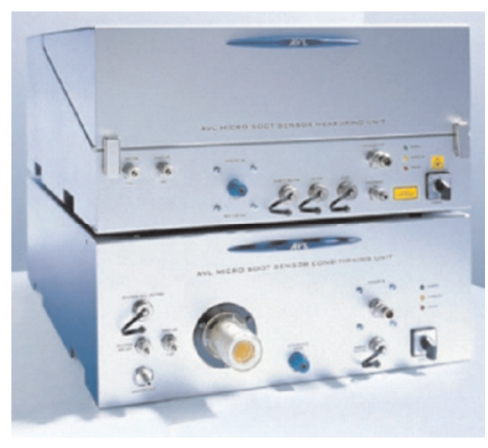

Fig. 3. Equipment used for measuring particulates in the range of: a) number and dimensional distribution - EEPS TSI 3090, b) concentrations - AVL MSS [3]

\subsection{RDE route}

The requirements for the RDE route are strictly defined. It consists of three driving cycles: urban, extra-urban and highway (Fig. 4).

The share of the traveled distance of individual stages in the whole test is about 33\% (Table 2). The ride took place in the afternoon, which allowed to avoid excessive traffic congestion.

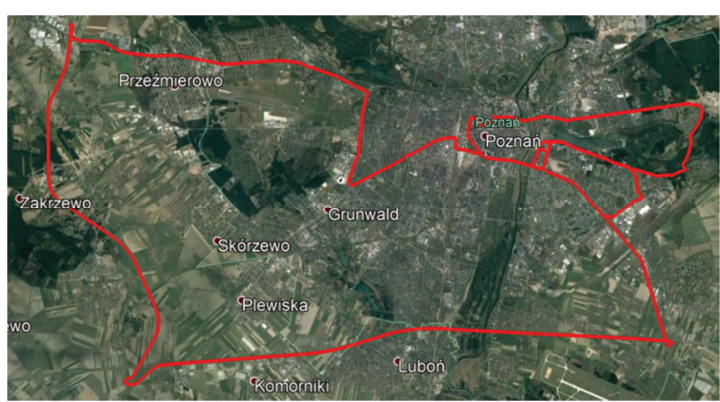

Fig. 4. The research route in accordance with the procedure RDE

Table 2. RDE cycles data

\begin{tabular}{|l|c|c|c|}
\cline { 2 - 4 } \multicolumn{1}{c|}{} & Urban & Extra-urban & Motorway \\
\hline Average speed $[\mathrm{km} / \mathrm{h}]$ & 25.62 & 73.83 & 112.99 \\
\hline Drive duration $[\mathrm{s}]$ & 4812 & 949 & 812 \\
\hline Distance $[\mathrm{km}]$ & 34.25 & 19.48 & 25.52 \\
\hline
\end{tabular}

\section{Research results}

\subsection{Urban cycle}

During the 80-minute drive in the urban cycle, nitrogen oxide emission values were obtained in accordance with the emission standards, according to which the tested vehicle was homologated (Fig. 5a). Fuel consumption was regular throughout the entire cycle (Fig. 5b). Driving in urban areas limits the possibility of $\mathrm{CO}_{2}$ emissions reducing due to congestion and obtaining average speeds of $25 \mathrm{~km} / \mathrm{h}$, as in the case of the test run (Table 2).

a)

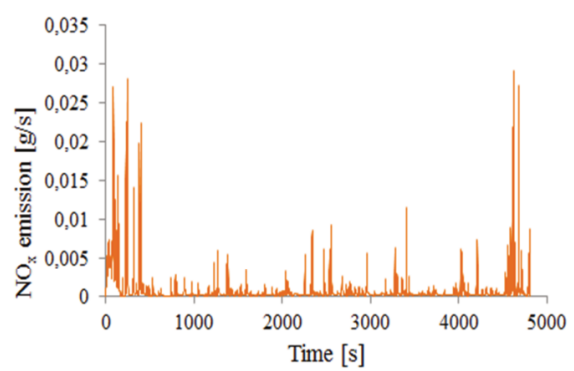

b)

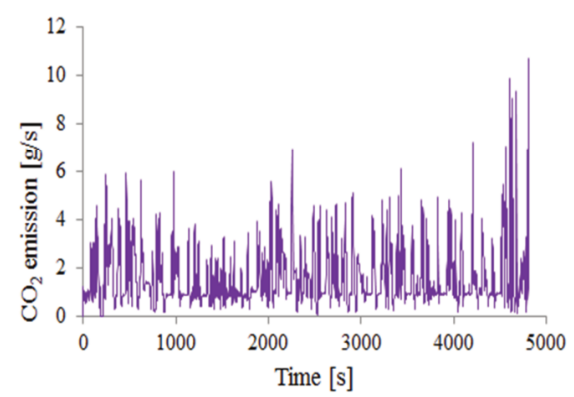

Fig. 5. Measured compounds emission per second: a) $\mathrm{NO}_{\mathrm{x}}$, b) $\mathrm{CO}_{2}$

The increased emission of particulates mass in the urban cycle could be caused by the cold start of the engine at the beginning of the tests (Fig. 6b). Despite the largest value of all the test stages, the result is still below the limits in the approval standard (Table 2). The increased number of solid particles with small diameters results from direct fuel injection, which promotes their formation (Fig. 6a). 


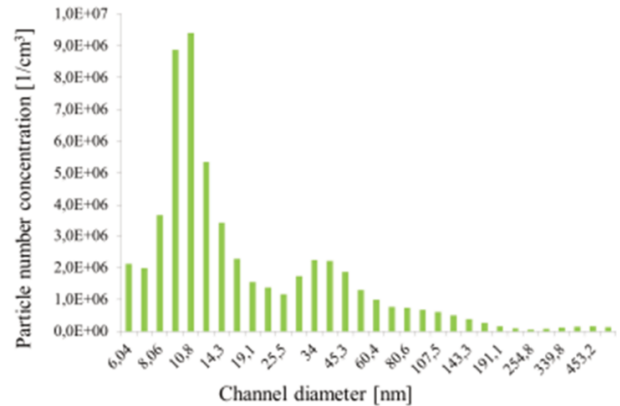

b)

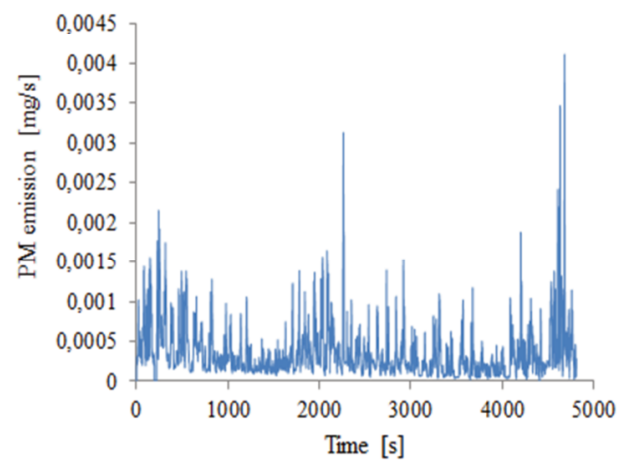

Fig. 6. Solid components of exhaust gases: a) particle number concentration, b) particle mass

With reference to the homologation standard of the tested vehicle, the admissible value was not exceeded for the compounds in the exhaust gases (Table 3).

Table 3. Specific distance emissions results during an urban cycle

\begin{tabular}{|l|c|c|}
\hline \multicolumn{2}{|c|}{$\begin{array}{c}\text { Specific distance emission during an urban } \\
\text { cycle }\end{array}$} & Euro 6b standard \\
\hline $\mathrm{NO}_{\mathrm{x}}[\mathrm{g} / \mathrm{km}]$ & 0.12 & 0.06 \\
\hline $\mathrm{CO}_{2}[\mathrm{~g} / \mathrm{km}]$ & 226.74 & - \\
\hline $\mathrm{PM}[\mathrm{mg} / \mathrm{km}]$ & 0.000952 & 0.0045 \\
\hline $\mathrm{PN}[1 / \mathrm{km}]$ & $5 \mathrm{e} 10$ & $6 \mathrm{e} 11$ \\
\hline
\end{tabular}

\subsection{Extra-urban cycle}

The shortest stage of the research was the extra-urban cycle. During the cycle, the driver drove a distance of 19 $\mathrm{km}$. In the initial phase of the test, lower speeds were maintained, which reflects the lower emission of nitrogen oxides, the formation of which is promoted by rapid acceleration. In the final stage of the cycle, the driver moved from the extra-urban area towards the motorway, which allowed to achieve higher speeds, thus increasing $\mathrm{NO}_{\mathrm{x}}$ emissions (Fig. 7a). The same trend can be observed in the case of $\mathrm{CO}_{2}$, which is directly connected to fuel consumption (Fig. 7b).

A three-fold reduction in solid particles mass emission in relation to the urban cycle was observed (Fig. 8b). At this stage of the research, the engine warmed up, which improves the fuel combustion conditions. As a result of the engine's achievement of an appropriate operating temperature, the time needed to evaporate the fuel has been shortened, due to which the emitted particulates number has been increased (Fig. 8a).

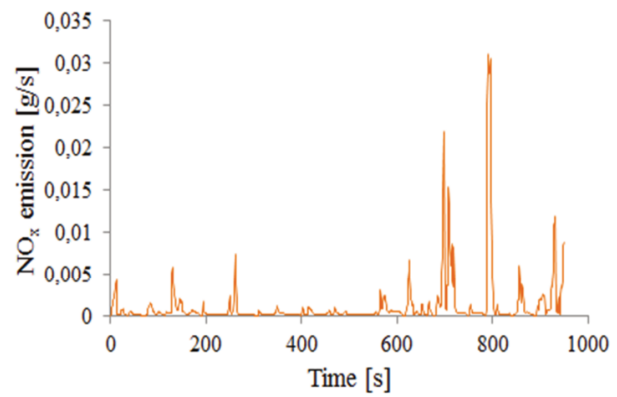

b)

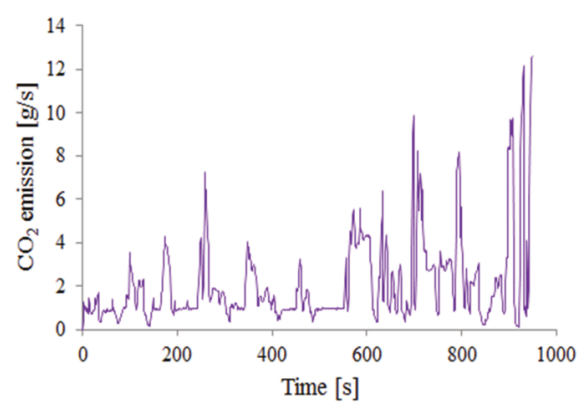

Fig. 7. Measured compounds emission per second: a) $\mathrm{NO}_{\mathrm{x}}$, b) $\mathrm{CO}_{2}$

a)

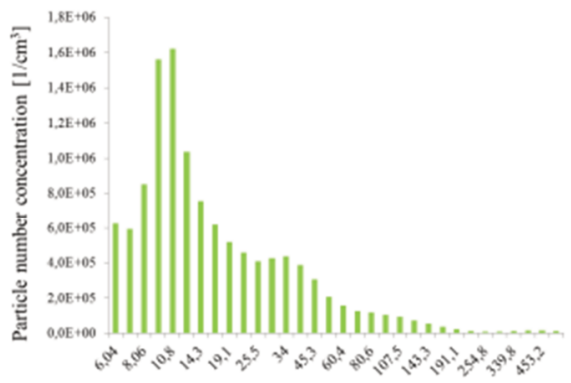

Channel diameter $[\mathrm{nm}]$

b)

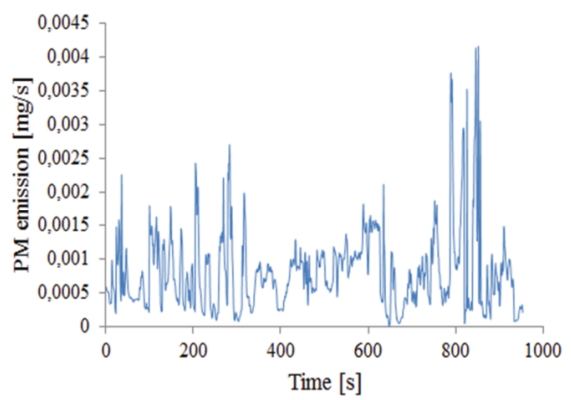

Fig. 8. Solid components of exhaust gases: a) particle number concentration, b) particle mass

The emission of nitrogen oxides reached a value similar to that determined in the Euro $6 \mathrm{~b}$ homologation standard (Table 4). The number of particles in relation to the distance was the smallest relative to the other parts of the RDE test.

Table 4. Specific distance emissions results during an extra-urban cycle

\begin{tabular}{|c|c|c|}
\hline \multicolumn{2}{|c|}{$\begin{array}{l}\text { Specific distance emission during an extra- } \\
\text { urban cycle }\end{array}$} & Euro $6 \mathrm{~b}$ standard \\
\hline $\mathrm{NO}_{\mathrm{x}}[\mathrm{g} / \mathrm{km}]$ & 0.057 & 0.06 \\
\hline $\mathrm{CO}_{2}[\mathrm{~g} / \mathrm{km}]$ & 134.6 & - \\
\hline $\mathrm{PM}[\mathrm{mg} / \mathrm{km}]$ & 0.000396 & 0.0045 \\
\hline $\mathrm{PN}[1 / \mathrm{km}]$ & $3 \mathrm{e} 9$ & $6 \mathrm{e} 11$ \\
\hline
\end{tabular}




\subsection{Motorway cycle}

Due to the speed characterizing the motorway crossing, its duration was the shortest. The initial stage of the cycle was characterized by higher speeds. At some moments, the vehicle has reached a speed of $130 \mathrm{~km} / \mathrm{h}$. This caused a rise in temperature in the combustion chamber, and consequently an increase in the emission of nitrogen oxides (Fig. 9a). Fuel consumption was uniform, increased compared to the extra-urban cycle, adequate to the need to achieve higher speeds and increased air resistance(Fig. 9b). a)

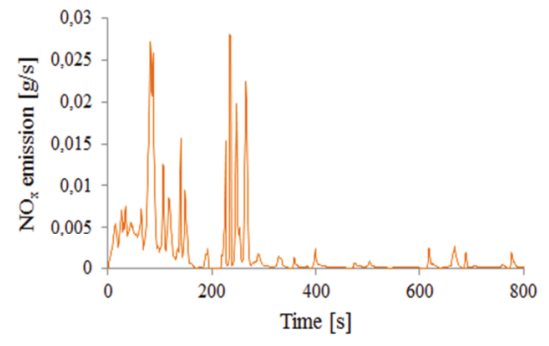

b)

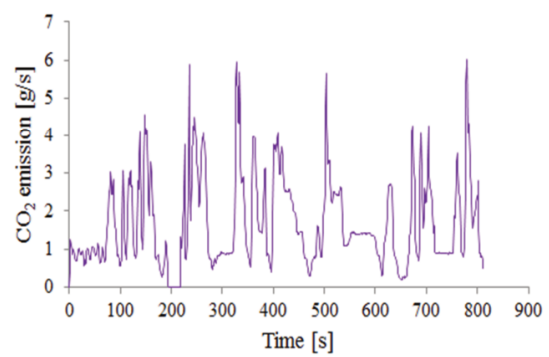

Fig. 9. Measured compounds emission per second: a) $\mathrm{NO}_{\mathrm{x}}$, b) $\mathrm{CO}_{2}$

Despite warming up the engine and reaching the right operating temperature, the emission of particulate mass is greater than during extra-urban drive, because the vehicle uses more fuel to maintain the set speed (Fig. 10b). The increase in fuel consumption is associated with an increase in the particulate number emission and has an impact on their dimensional distribution (Fig. 10a). Compared to the other stages, an increase in particle diameter was noted.

a)

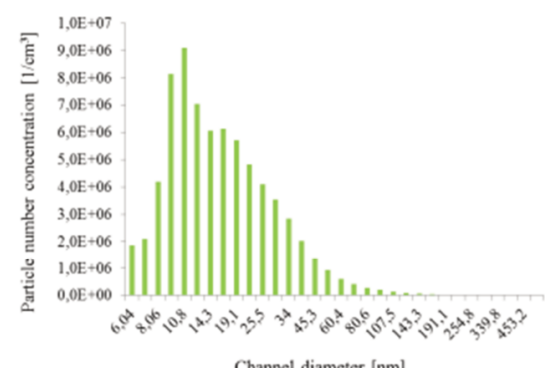

b)

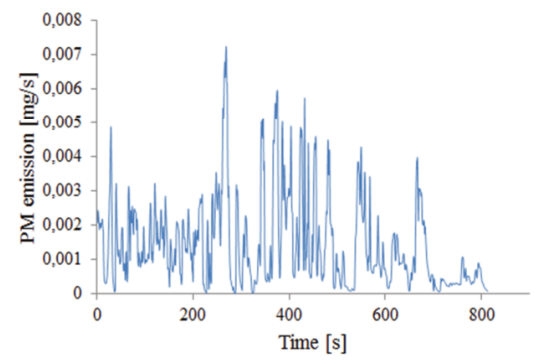

Fig. 10. Solid components of exhaust gases: a) particle number concentration, b) particle mass
The effect of increased fuel consumption can be noticed for the specific distance emission of the particulates number, which significantly approached the limit value of the Euro $6 \mathrm{~b}$ standard (Table 5). Increasing the average speed to $113 \mathrm{~km} / \mathrm{h}$ caused an increase in temperature in the combustion chambers and exceeding the limit value of nitrogen oxides emission.

Table 5. Specific distance emissions results during an extra-urban cycle

\begin{tabular}{|l|c|c|}
\hline \multicolumn{2}{|c|}{$\begin{array}{c}\text { Specific emission during a motorway } \\
\text { cycle }\end{array}$} & Euro 6b standard \\
\hline $\mathrm{NO}_{\mathrm{x}}[\mathrm{g} / \mathrm{km}]$ & 0.057 & 0.06 \\
\hline $\mathrm{CO}_{2}[\mathrm{~g} / \mathrm{km}]$ & 134.6 & - \\
\hline $\mathrm{PM}[\mathrm{mg} / \mathrm{km}]$ & 0.000396 & 0.0045 \\
\hline $\mathrm{PN}[1 / \mathrm{km}]$ & $3 \mathrm{e} 9$ & $6 \mathrm{e} 11$ \\
\hline
\end{tabular}

\subsection{Total RDE test}

During the total RDE test, fuel consumption reaches the highest values at the end of the stage, which mostly corresponds to the motorway's movement (Fig. 11b). The emission of nitrogen oxides in the initial and final phase of the test corresponds to the specificity of moving in urban and motorway conditions, which was confirmed during the discussion of individual stages of the test (Fig. 11a).

a)

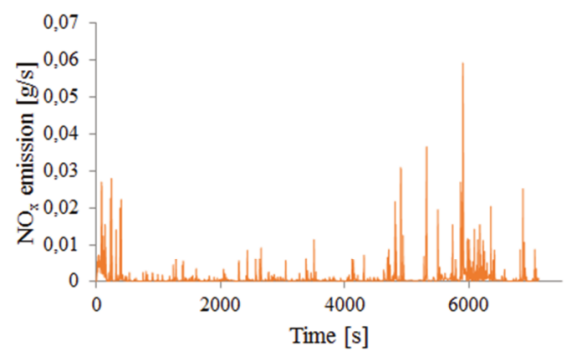

b)

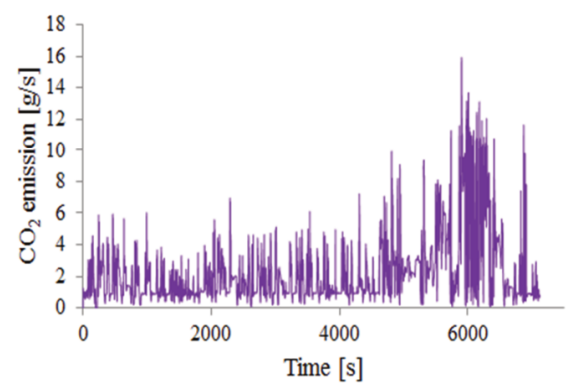

Fig. 11. Measured compounds emission per second: a) $\mathrm{NO}_{\mathrm{x}}$, b) $\mathrm{CO}_{2}$

The dominance of small diameter particles throughout the test confirms the low impact of the conditions in which the vehicle moves (Fig. 128a). The formation of this type of particles is mainly caused by the type of fuel injection in a given engine type. Emission of particulate mass is associated with increased fuel consumption in the final test phase (Fig. 12b).

Along with the RDE test procedure, the conformity factor $(\mathrm{CF})$ was introduced, amounting to 2 . After taking the factor into account, the permissible value of nitrogen oxides emission for the entire test was exceeded (Table 6). No exceeded value for other compounds. 


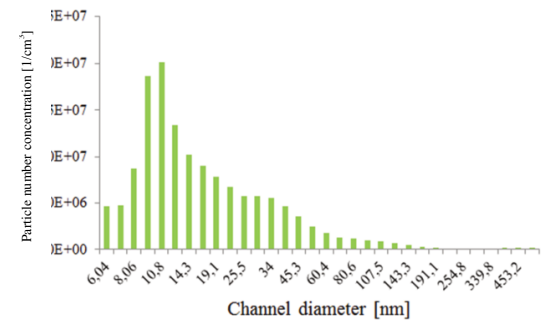

b)

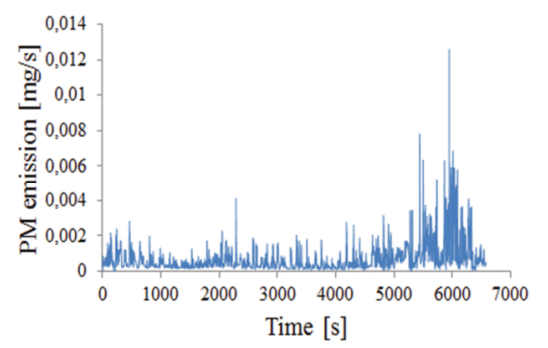

Fig. 12. Solid components of exhaust gases: a) particle number concentration, b) particle mass

Table 6. Specific distance emissions results during an extra-urban cycle

\begin{tabular}{|l|c|c|}
\hline \multicolumn{2}{|c|}{ Specific distance emission during a mo- } & Euro 6b standard \\
torway cycle & 0.09 & 0.06 \\
\hline $\mathrm{NO}_{\mathrm{x}}[\mathrm{g} / \mathrm{km}]$ & 188.12 & - \\
\hline $\mathrm{CO}_{2}[\mathrm{~g} / \mathrm{km}]$ & 0.000521 & 0.0045 \\
\hline $\mathrm{PM}[\mathrm{mg} / \mathrm{km}]$ & $1.6 \mathrm{e} 11$ & $6 \mathrm{e} 11$ \\
\hline $\mathrm{PN}[-/ \mathrm{km}]$ & & \\
\hline
\end{tabular}

\section{Summary}

Current legal regulations force vehicle manufacturers to apply exhaust aftertreatment systems. The tested vehicle was not equipped with a particulate filter, which resulted in increased emission of small particle sizes. They pose a special threat in urban areas because they have a negative impact on human life and health. The introduction of a limit of the number of particulates was necessary, which is confirmed by the results of tests in which the mass emission of solid particles is several times lower than the permissible value, while their number reaches a similar order of magnitude to the limit specified in the Euro $6 \mathrm{~b}$ standard. Nitrogen oxide emission was exceeded during motorway cycle, which was probably caused by the increased temperature in the combustion chamber due to the need to maintain high vehicle speed. Fuel consumption was adequate to the conditions specific to a given cycle. The highest values of carbon dioxide emissions have been registered for urban cycle, in which the use of methods to reduce fuel consumption is the most difficult due to the occurrence of congestion and increased frequency of acceleration and deceleration of the vehicle. The large number of particles with small diameters is a phenomenon characteristic of this type of engines, therefore it is necessary to improve the exhaust gas aftertreatment systems and adapt them to the manufactured vehicles. Research in real traffic conditions is currently the best method to verify the operation of exhaust aftertreatment systems and to determine the actual emission of harmful and toxic exhaust components.

\section{Bibliography}

[1] AIKAWA, K., JETTER, J.J. Impact of gasoline composition on particulate matter emissions from a direct-injection gasoline engine. Applicability of the particulate matter index. Int. J. Engine Res. 2014, 15, 298-306.

[2] FUĆ, P., SOKOLNICKA, B., SZYMLET, N., SIEDLECKI, M. Analiza emisji węglowodorów z pojazdu z bezpośrednim wtryskiem benzyny w rzeczywistych warunkach ruchu. Bezpieczeństwo i ekologia, Autobusy. 2017, 12.

[3] MERKISZ, J., PIELECHA, J., LIJEWSKI, P. et al. Exhaust emissions from vehicles in real traffic conditions in the Poznan agglomeration. WIT Transactions on Ecology and the Environment. 2013, 174, 27-38.

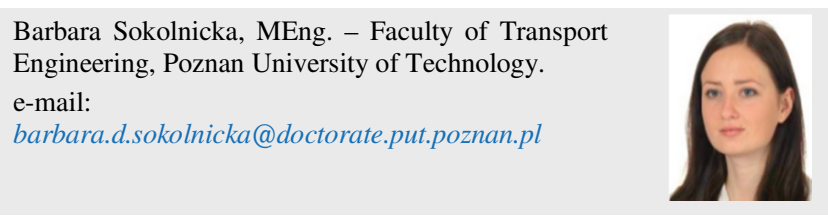

Maciej Siedlecki, MEng. - Faculty of Transport Engineering, Poznan University of Technology. e-mail: maciej.s.siedlecki@doctorate.put.poznan.pl

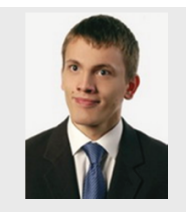

Paweł Fuć, DSc., DEng. - Faculty of Transport Engineering, Poznan University of Technology. e-mail: pawel.fuc@put.poznan.pl
[4] MERKISZ, J., PIELECHA, J., NOWAK, M. Emisja zanieczyszczeń z pojazdów w rzeczywistych warunkach ruchu na przykładzie aglomeracji poznańskiej. Postępy Nauki i Techniki. 2012, 15.

[5] MUÑOZ, M., HAAG, R., HONEGGER, P. et al. Coformation and co-release of genotoxic PAHs, alkyl-PAHs and soot nanoparticles from gasoline direct injection vehicles. Athmospheric Environment. 2018, 178, 242-254.

[6] SIEDLECKI, M., GALANT, M., RYMANIAK, Ł., ZIÓŁKOWSKI, A. Badania emisji zanieczyszczeń pojazdu wyposażonego $\mathrm{w}$ silnik $\mathrm{z}$ bezpośrednim wtryskiem benzyny w rzeczywistych warunkach eksploatacji. Bezpieczeństwo i ekologia, Autobusy. 2017, 12.

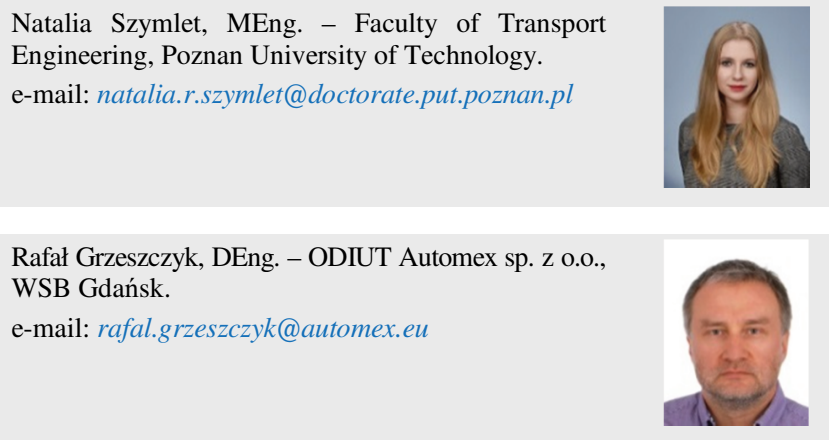

